\title{
ВАГОВІ ХАРАКТЕРИСТИКИ ТА ГАЛУЗІ РАЦІОНАЛЬНОГО ВИКОРИСТАННЯ СТАЛЕВИХ ЦЕНТРАЛЬНО СТИСНУТИХ КОЛОН
}

\section{WEIGHT CHARACTERISTICS AND AREAS OF RATIONAL USE OF CENTRAL COMPRESSED STEEL COLUMNS}

\begin{abstract}
Пашинський В.А., д.т.н., проф., Пашинський М.В., к.т.н., Скриннік I.O., к.т.н., доц., Дарієнко В.В., к.т.н., доц. (Центральноукраїнський національний технічний університет, м. Кропивницький)
\end{abstract}

Pashynskyi V.A., Sc.D., prof, Pashynskyi M.V., PhD, Dariienko V.V., $\mathrm{PhD}$, associate professor, Skrynnik I.O., PhD, associate professor (Central Ukrainian National Technical University, Kropyvnytskyi)

Анотація. За результатами експериментального проектування цеентрально стиснутих сталевих колон шести типів виявлені залежності їх маси від висоти й навантаження. За укрупненими розцінками оцінена вартість виготовлення та монтажу колон різних типів. Результати роботи дозволяють орієнтовно встановити металоємність і вартість колон різних типів за відомою висотою й навантаженням та обрати раціональний тип колони.

Summary. Six types of central compressed steel columns are considered: rolled and welded I-beams, square pipes, two channel bars connected via planks, four metal corners connected via planks or lattices. The experimental design of columns of all types was carried out with various combinations of heights up to 20 meters and the load on the column up to $9 \mathrm{MN}$.

It is shown that the sections of welded I-beams, as well as four-branch columns connected via planks or lattices can be selected for all combinations of height and load within the specified limits. The areas of possible use of columns from rolled I-beams, square pipes and two channel bars connected via planks are limited by the serviceability limit and ultimate limit state of the rolled profiles from the respective assortments.

According to the design results, the dependencies of the optimum cross-sectional dimension of the welded I-beams and four metal corners connected via planks or lattices on the load and the height of the column are established and described by analytical expressions. A unified type of analytical dependence of the linear mass of central compressed columns on their height and current load is proposed. The coefficients of these dependences for the columns of the six types are obtained by approximating the results of experimental design using the least squares method.

According to the results of a comparative analysis, the areas of rational use of central compressed columns of six types are set according to the criteria of metal consumption and cost. In most cases, four metal corners connected via planks or lattices is characterized by the least metal consumption, but at low heights and high loads - 
welded I-columns. According to the cost criterion, in most cases it is better to have welded I-columns, and four metal corners connected via planks or lattices have the lowest cost at high heights and small longitudinal forces.

Ключові слова: сталеві колони, металоємність, області раціонального використання.

Keywords: steel columns, metal consumption, areas of rational use.

Постановка проблеми. При компонуванні каркасів будівель виникає необхідність оцінити доцільність використання сталевих колон різних типів. Відомо, що при малих висотах і великих навантаженнях краще використовувати колони суцільного перерізу, а при великих висотах i малих навантаженнях кращими $\epsilon$ колони наскрізного перерізу. Чітке розмежування областей раціонального використання колон різних типів залежно від їх висоти й навантаження відсутнє. Вибір кращого конструктивного рішення можна здійснити шляхом попереднього оцінювання металоємності та вартості колон різних типів ще до їх початку реального проектування. Для цього потрібно встановити залежності показників металоємності колон різних типів від діючого навантаження та висоти. Окрім того, вимагає розв'язання також питання вибору оптимальних конструктивних параметрів колон.

Аналіз відомих досліджень i публікацій. Для попереднього оцінювання металоємності несучих конструкцій в літературі зазвичай рекомендується виконувати їх наближені розрахунки. Методика проектування сталевих центрально стиснутих колон регламентована нормами [1] та детально описана в навчальній літературі, наприклад [2]. Одним 3 перших способів визначення витрат сталі без проектування конструкції є метод характеристик маси, описаний в [3]. Цей метод не набув поширення унаслідок його складності та трудомісткості, близької до виконання наближених розрахунків. Використання досвіду проектування аналогічних конструкцій може п-ризвести до значних похибок.

Досить перспективний підхід запропоновано в роботі [4], де за результатами експериментального проектування отримані та описані аналітичними виразами залежності витрат сталі на балкові конструкції від величини прольоту й погонного навантаження. В [4] також обгрунтовані укрупнені розцінки, які дають змогу наближено оцінити вартість виготовлення й монтажу балок і колон різних типів. Межі несучої здатності сталевих центрально стиснутих колон деяких типів залежно від їх висоти проаналізовані в роботі [5]. 3 викладеного слідує доцільність узагальнення результатів експериментального проектування сталевих центрально стиснутих колон різних типів для попереднього оцінювання металоємності та вибору раціонального конструктивного рішення.

Мета дослідження полягає в тому, щоб за результатами експериментального проектування виявити оптимальні значення 
конструктивних параметрів для сталевих колон, встановити залежності їх металоємності від висоти й поздовжньої сили, а також окреслити області раціонального використання центрально стиснутих колон різних типів.

Вихідні дані. Для порівняльного аналізу використані результати експериментального проектування центрально стиснутих сталевих колон шести типів, перелічених у таблиці 1. Проектування в основному виконувалося в магістерських роботах під керівництвом авторів даної статті. Колони усіх типів запроектовані для різних комбінацій висоти L i граничного розрахункового значення поздовжньої сили N. Згідно 3 вказівками ДБН [1], усі колони виконані з маловуглецевої сталі С 235, яка найчастіше використовується в колонах будівель класів відповідальності CC1 та CC2. Підбір перерізів здійснено в середовищі Microsoft Excel згідно з вимогами норм проектування сталевих конструкцій [1].

Таблиця 1

Характеристики запроектованих колон

\begin{tabular}{|l|c|c|c|c|}
\hline \multicolumn{1}{|c|}{ Типи колон } & $\mathrm{L}, \mathrm{M}$ & $\mathrm{N}, \mathrm{MH}$ & Кількість & $\mathrm{g}$, кг/м \\
\hline 1. Прокатні двотаври & $2 \ldots 14$ & $0,5 \ldots 7,0$ & $98 / 73$ & $41 \ldots 291$ \\
\hline 2. Зварні двотаври & $2 \ldots 20$ & $0,1 \ldots 9,0$ & $150 / 150$ & $7 \ldots 462$ \\
\hline 3. Квадратні труби & $2 \ldots 16$ & $0,5 \ldots 3,5$ & $56 / 37$ & $21 \ldots 122$ \\
\hline 4. Два швелери на планках & $2 \ldots 20$ & $0,5 \ldots 2,5$ & $50 / 37$ & $23 \ldots 107$ \\
\hline 5. Чотири кутники на планках & $4 \ldots 20$ & $1,0 \ldots 9,0$ & $25 / 25$ & $50 \ldots 467$ \\
\hline 6. Чотири кутники на решітках & $2 \ldots 20$ & $0,1 \ldots 9,0$ & $140 / 140$ & $13 \ldots 424$ \\
\hline
\end{tabular}

3 таблиці видно, що висота колон не перевищувала 20 м. Це значення в основному обумовлене величинами радіусів інерції прокатних профілів та обмеженням граничної гнучкості колон, рівним 150. Максимальні значення поздовжніх сил визначалися за несучою здатністю найбільших профілів у використаних сортаментах. У графі "Кількість" через дріб указана кількість можливих комбінацій висоти й навантаження та фактична кількість підібраних перерізів колон. Остання може бути дещо меншою внаслідок недостатньої несучої здатності профілів використаних сортаментів для підбору перерізів колон при великих значеннях висоти й навантаження. Остання графа таблиці 1 містить межі зміни значень погонної маси стержнів запроектованих колон.

У результаті експериментального проектування отримані табличні залежності погонної маси стержнів колон усіх шести типів від висоти та величини поздовжньої сили, а також залежності оптимального габариту перерізу стержнів складених колон від тих же факторів. Ці дані використані нижче для узагальнення й порівняння вагових характеристик $\mathrm{i}$ вартості колон різних типів.

Конструктивні особливості та межі можливого використання колон. Колони типу 1 запроектовані з прокатних двотаврів колонного 
типу з паралельними гранями поличок за ГОСТ 26020-83. Колони третього типу виконані з гнутих замкнутих квадратних профілів за ГОСТ 8639-82.

Зварні колони типу 2 мають ширину поличок, рівну висоті двотавра, та найменші можливі за умовами місцевої стійкості товщини поличок і стінки. Шляхом чисельної оптимізації за критерієм мінімальних витрат сталі встановлена залежність оптимальної висоти перерізу двотавра та рівної їй ширини полички (в міліметрах) від висоти колони L (в метрах) та поздовжньої сили N (в меганьютонах):

$$
h=81+21,5 \cdot L+63 \cdot N-0,8 N \cdot L, \text { мм. }
$$

Три останні типи представляють наскрізні колони. Колони типу 4 виконані з двох швелерів за ДСТУ 3436-96 на планках у двох площинах. Встановлено, що для швелерів 27У...40У габарит перерізу (відстань між обушками швелерів) доцільно приймати рівним висоті швелера. При менших профілях габарит перерізу повинен перевищувати висоту швелера, виходячи 3 конструктивної вимоги щодо відстані між перами поличок швелерів. Крок планок доцільно встановлювати таким, щоб гнучкість гілки колони на відстані між планками була рівною 35...40.

Колони типу 5 і 6 запроектовані з чотирьох кутників за ГОСТ 8509-93 на планках чи на решітках у чотирьох площинах. Решітки в колонах типу 6 виконані трикутними, а при надмірній гнучкості гілок встановлювалися додаткові стійки. В колонах типу 5 крок планок доцільно встановлювати таким, щоб гнучкість гілки колони на відстані між планками була рівною 25 ..35. Шляхом варіантного проектування встановлено, що оптимальний за витратами сталі габарит перерізу стержня колони з чотирьох кутників на планках дорівнює

$$
B=57,4 \sqrt[3]{N} \sqrt{L}+360 \text { мм }
$$

а для колони $з$ чотирьох кутників на решітках

$$
B=165 \sqrt[3]{N} \sqrt{L}-36 \mathrm{мм}
$$

де $\mathrm{N}$ - поздовжня сила в меганьютонах;

$\mathrm{L}$ - висота колони в метрах.

Порівняння показало, що при великих висотах i навантаженнях оптимальний габарит колон на решітках може бути в 1,5 рази більшим, ніж для колон на планках. Це істотно збільшує радіус інерції перерізу колони на решітках та її загальну стійкість.

У результаті експериментального проектування встановлено, що колони із зварних двотаврів, а також чотиригілкові колони з кутників на планках чи решітках можуть бути запроектовані для усіх комбінацій висоти в межах до 20 м та навантаження в межах до 9 МН. Можливість використання колон 3 прокатних двотаврів, 3 квадратних труб та 3 двох швелерів на планках обмежена характеристиками профілів чинних сортаментів. Ці обмеження відображені на рисунку 1. 


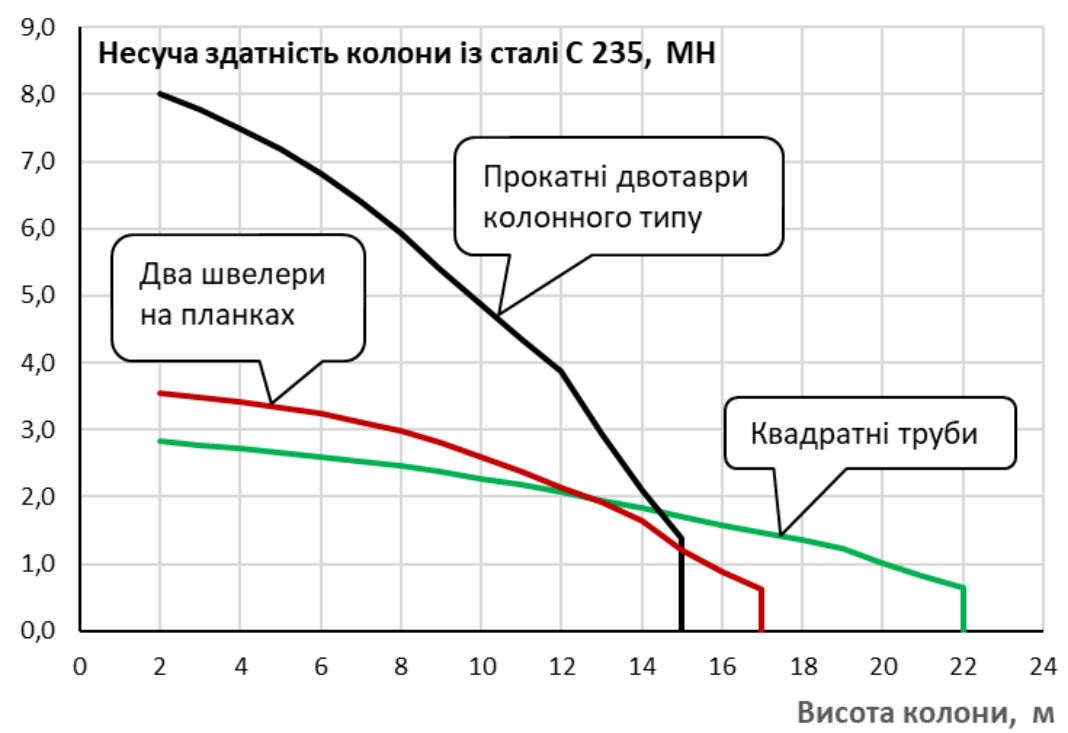

Рис. 1. Межі можливого використання центрально стиснутих колон

Графіки 3 рисунка 1 дозволяють при відомих значеннях висоти й навантаження оцінити можливість використання колон типів 1, 3 i 4. Наприклад, при висоті $\mathrm{L}=8 \mathrm{~m}$ і граничному розрахунковому значенні поздовжньої сили $\mathrm{N}=4 \mathrm{MH}$ можна запроектувати колону з прокатного двотавра. Колони з квадратних труб та швелерів на планках матимуть недостатню несучу здатність унаслідок обмежень відповідних сортаментів.

Вагові характеристики колон встановлені й проаналізовані за результатами експериментального проектування, охарактеризованими в таблиці 1. Основною ваговою характеристикою є погонна маса стержня колони. Аналіз результатів експериментального проектування показав, що залежність погонної маси колон усіх шести типів від висоти L та навантаження $\mathrm{N}$ можна описати уніфікованим виразом:

$$
g=a(N+b) \exp (c L)-d,
$$

де $\mathrm{L}$ - висота колони в метрах;

$\mathrm{N}$ - поздовжня сила в меганьютонах.

Коефіцієнти залежностей (4) для усіх шести типів колон, обчислені на основі методу найменших квадратів [6] з використанням функції Microsoft Excel "Пошук рішення", наведені в таблиці 2. 
Таблиця 2

Коефіцієнти для визначення погонної маси стержнів колон

\begin{tabular}{|l|r|r|r|r|}
\hline \multirow{2}{*}{\multicolumn{1}{|c|}{ Типи колон }} & \multicolumn{4}{c|}{ Коефіцієнти формули (4) } \\
\cline { 2 - 5 } & \multicolumn{1}{c|}{$\mathrm{a}$} & \multicolumn{1}{c|}{$\mathrm{c}$} & \multicolumn{1}{c|}{$\mathrm{d}$} \\
\hline 1. Прокатні двотаври & 36,14 & 6,30 & 0,029 & 248 \\
\hline 2. Зварні двотаври & 33,33 & 7,165 & 0,0164 & 248 \\
\hline 3. Квадратні труби & 33,07 & 6,57 & 0,014 & 221 \\
\hline 4. Два швелери на планках & 38,57 & 15,84 & 0,0049 & 616 \\
\hline 5. Чотири кутники на планках & 41,35 & 2,12 & 0,0095 & 83 \\
\hline 6. Чотири кутники на решітках & 39,8 & 1,64 & 0,0043 & 59 \\
\hline
\end{tabular}

Підстановка коефіцієнтів 3 таблиці 2 до (4) дає робочі формули для наближеного визначення погонної маси стержнів колон усіх типів без виконання розрахунків з підбору перерізу. Повна маса стержня колони в тонах обчислюється шляхом множення погонної маси на висоту колони:

$$
G=g \cdot L \cdot k / 1000,
$$

Конструктивний коефіцієнт маси $k$ враховує витрати сталі на базу, оголовок та інші допоміжні деталі колони і може бути прийнятий рівним $\mathrm{k}=1,1$ для суцільних колон $\mathrm{i} \mathrm{k}=1,2$ для наскрізних колон $[2,3]$.

Вартість колон наближено оцінюється за укрупненими розцінками [4], які враховують тип колони, ціну використаного прокату та допоміжних матеріалів, вартість виготовлення та монтажу. Повна кошторисна вартість колони визначається за формулою

$$
C_{K}=G\left(C_{\Pi} K_{3}+K_{M}\right),
$$

де $G$ - повна маса колони в тонах за (5);

$C_{\Pi}-$ ринкова ціна прокату за сайтами торгівельних організацій, грн/т;

$K_{3}$ - коефіцієнт заводської вартості;

$K_{M}=2100-$ коефіцієнт вартості монтажу.

Коефіцієнт заводської вартості $K_{3}$ дорівнює 1,11 для конструкцій 3 прокатних двотаврів, 1,19 - для конструкцій із зварних двотаврів та 1,49 для наскрізних конструкцій.

Результати оцінювання за формулою (6) дозволити порівняти усі запроектовані колони за критерієм вартості.

Області раціонального використання колон розглянутих типів встановлені за критеріями металоємності та вартості. 3 результатів експериментального проектування та оцінювання вартості для кожної комбінації навантаження й висоти колони вибрані типи колон, які мають найменшу погонну масу та найменшу вартість. Результати цього вибору для проаналізованих вище комбінацій навантаження й висоти колони наведені в таблиці 3. 
Таблиця 3

Раціональні типи колон за критеріями металоємності та вартості

\begin{tabular}{|c|c|c|c|c|c|c|c|c|c|c|c|c|c|c|}
\hline \multirow{2}{*}{$\begin{array}{c}\mathrm{N} \\
\mathrm{MH}\end{array}$} & \multicolumn{7}{|c|}{$\begin{array}{l}\text { Типи колон } 3 \text { найменшою } \\
\text { металоємністю при висоті }\end{array}$} & \multicolumn{7}{|c|}{$\begin{array}{c}\text { Типи колон з найменшою } \\
\text { вартістю при висоті }\end{array}$} \\
\hline & 4 & 6 & 8 & $\underline{0}$ & 12 & 14 & 16 & 4 & 6 & 8 & 10 & 12 & 14 & 16 \\
\hline 1 & 2 & 3 & 6 & 6 & 6 & 6 & 6 & 2 & 2 & 2 & 6 & 6 & 6 & 6 \\
\hline 2 & 2 & 3 & 6 & 6 & 6 & 6 & 6 & 2 & 2 & 2 & 2 & 6 & 6 & 6 \\
\hline 3 & 2 & 3 & 6 & 6 & 6 & 6 & 6 & 2 & 2 & 2 & 2 & 2 & 2 & 6 \\
\hline 4 & 2 & 2 & 6 & 6 & 6 & 6 & 6 & 2 & 2 & 2 & 2 & 2 & 2 & 2 \\
\hline 5 & 2 & 2 & 2 & 6 & 6 & 6 & 6 & 2 & 2 & 2 & 2 & 2 & 2 & 2 \\
\hline 6 & 2 & 2 & 2 & 6 & 6 & 6 & 6 & 2 & 2 & 2 & 2 & 2 & 2 & 2 \\
\hline 7 & 2 & 2 & 2 & 0 & 6 & 0 & 6 & 2 & 2 & 2 & 2 & 2 & 2 & 2 \\
\hline 8 & 2 & 2 & 2 & 6 & 6 & 6 & 6 & 2 & 2 & 2 & 2 & 2 & 2 & 2 \\
\hline
\end{tabular}

3 таблиці видно, що у більшості випадків найлегшими є колони типу 6 , тобто чотиригілкові колони з кутників на решітках. При малих висотах $\mathrm{i}$ великих навантаженнях більш раціональними $є$ колони типу 2 , тобто зварні двотаврові колони. Колони типу 3 (з квадратних труб) доцільно використовувати лише при висоті близько 6 м та навантаженнях до $3 \mathrm{MH}$.

За критерієм вартості, відображеним у правій частині таблиці 3 , у переважній більшості випадків кращими є зварні двотаврові колони (тип 2). Колони з чотирьох кутників на решітках (тип 6) мають найменшу вартість при великих висотах і малих поздовжніх силах.

У більшості випадків таблиця 3 дозволяє досить впевнено обрати раціональну конструкцію центрально стиснутої сталевої колони. Існують комбінації висоти й навантаження, при яких критерії металоємності та вартості співпадають. Наприклад, при висоті колони $\mathrm{L}=6$ м i навантаженні $\mathrm{N}=5 \mathrm{MH}$ оптимальним рішенням буде зварна двотаврова колона (тип 2). При $\mathrm{L}=12 \mathrm{м}$ та $\mathrm{N}=2 \mathrm{MH}$ слід вибрати чотиригілкову колону на решітках (тип 6).

У багатьох випадках вибір за критеріями металоємності та вартості дає різні результати. Наприклад, при $\mathrm{L}=10$ м та $\mathrm{N}=4 \mathrm{MH}$ найлегшою буде чотиригілкова колона на решітках (тип 6), а найдешевшою - зварна двотаврова колона. У подібних ситуаціях вибір типу колони слід робити 3 
урахуванням архітектурно-конструктивних і технологічних вимог, витрат на транспортування виготовлених колон, а також інших чинників.

Більш обгрунтований вибір раціонального типу колони можна зробити в результаті проведення аналізу в такому порядку:

1) за графіком рисунка 1 оцінюється можливість використання різних типів колон при заданих значеннях висоти й навантаження;

2) за формулами (4), (5) та коефіцієнтами 3 таблиці 2 обчислюються значення погонної та повної маси колон тих типів, які мають достатню несучу здатність при заданих значеннях висоти й навантаження;

3) за формулою (6) 3 урахуванням актуальних цін прокату визначаються вартості колон обраних типів.

Оптимальне конструктивне рішення обирається за найменшими показниками металоємності та вартості колон. Якщо ці показники не співпадають, тип колони слід обрати за мінімальним значенням одного показника (витрат сталі чи вартості) при умові близькості до мінімуму альтернативного показника.

При виборі раціонального конструктивного рішення слід також враховувати конструктивні та архітектурні вимоги, можливості отримання необхідного сталевого прокату, а також організаційні й технологічні можливості виробника конструкцій та будівельно-монтажної організації. Ці міркування можуть обумовити вибір, дещо відмінний від оптимального варіанта колони з мінімальною металоємністю чи мінімальною вартістю.

У випадку вибору колони із зварного двотавра, або наскрізної чотиригілкової колони на планках чи на решітках іï проектування рекомендується розпочинати 3 встановлення оптимального габариту поперечного перерізу за формулами (1), (2) або (3). Подальші розрахунки та конструювання колон слід виконувати згідно з вимогами норм [1] та рекомендаціями довідкової літератури.

\section{Висновки та перспективи подальших досліджень.}

1. Здійснене розмежування областей використання колон різних типів за критеріями металоємності та вартості дозволяє обрати раціональне конструктивне рішення сталевої центрально стиснутої колони.

2. У більшості випадків доцільно використовувати центрально стиснуті колони із зварних двотаврів та 3 чотирьох кутників на решітках. Інші типи колон є менш ефективними, але можуть бути використані 3 архітектурних, конструктивних чи технологічних міркувань.

3. Отримані залежності вагових характеристик колон від висоти й навантаження можна використати при виборі раціонального конструктивного рішення та при орієнтовному оцінюванні металоємності несучих конструкцій до початку їх проектування.

4. Виявлені залежності оптимальної висоти зварного двотавра та оптимального габариту перерізу чотиригілкової колони від ії висоти й 
навантаження дозволяють запроектувати колони цих типів 3 мінімально можливими витратами сталі.

5. Подальші дослідження орієнтуються на аналіз вагових показників сталевих конструкцій інших типів (позацентрово стиснуті колони, ферми та інші). Результати досліджень розширять можливості вибору оптимальних конструктивних форм сталевих конструкцій.

\section{References}

1. DBN V.2.6-198:2014. Stalevi konstruktsii. Normy proektuvannia. Kyiv: Minrehion Ukrainy, 2014. 199 s.

2. Lykhtarnykov Ya.M. Variantnoe proektirovanie i optimizatsiya stalnyih konstruktsiy. Moskva: Stroiizdat, 1979. 319 s.

3. Metallicheskie konstruktsii. Uchebnik dlia studentov vysshykh uchebnykh zavedenii / Yu.Y. Kudyshyn i dr.; pod redaktsyei Yu.Y. Kudyshyna. 10-e izdanye. M.: Izdatelskyi tsentr "Akademia", 2007. $688 \mathrm{s.}$

4. Pashynskyi V.A., Skrynnik I.O., Kharchenko I.V., Khachaturian S.L. Vahovi kharakterystyky ta oblasti ratsionalnoho vykorystannia stalevykh balok u budivliakh ta konstruktsiiakh vantazhopidiomnykh mashyn // Tsentralnoukrainskyi naukovyi visnyk. Tekhnichni nauky. Vyp. 1(32). Kropyvnytskyi: TsNTU. 2019. - S. 248-235.

5. Pashynskyi V.A., Vasylenko A.V., Yaroshchuk I.K. Mezhi ratsionalnoho vykorystannia prokatnykh profiliv $\mathrm{u}$ tsentralno stysnutykh kolonakh // Budivelni konstruktsii, budivli ta sporudy tretoho tysiacholittia. Zbirnyk materialiv naukovopraktychnoi internet-konferentsii. - Kherson: KhDAU, 2017 - s. 15-19.

6. Venttsel E.S. Teoryia veroiatnostei / E.S. Venttsel. - M.: Nauka. - 1969. - 576 s.

\section{Список використаної літератури}

1. ДБН В.2.6-198:2014. Сталеві конструкції. Норми проектування. Київ: Мінрегіон України, 2014. 199 с.

2. Лихтарников Я.М. Вариантное проектирование и оптимизация стальных конструкций. Москва: Стройиздат, 1979. 319 с.

3. Металлические конструкции. Учебник для студентов высших учебных заведений / Ю.И. Кудишин и др.; под редакцией Ю.И. Кудишина. 10-е издание. М.: Издательский центр "Академия", 2007. 688 с.

4. Пашинський В.А., Скриннік I.О., Харченко І.В., Хачатурян С.Л. Вагові характеристики та області раціонального використання сталевих балок у будівлях та конструкціях вантажопідйомних машин // Центральноукраїнський науковий вісник. Технічні науки. Вип. 1(32). Кропивницький: ЦНТУ. 2019. - С 248-235.

5. Пашинський В.А., Василенко А.В., Ярощук І.К. Межі раціонального використання прокатних профілів у центрально стиснутих колонах // Будівельні конструкції, будівлі та споруди третього тисячоліття. Збірник матеріалів науковопрактичної інтернет-конференції. - Херсон: ХДАУ, 2017 - с. 15-19.

6. Вентцель Е.С. Теория вероятностей / Е.С. Вентцель. - М.: Наука. - 1969. $576 \mathrm{c}$. 